Cecilia Laspoumaderes ORCID iD: 0000-0001-7790-2975

\title{
Effect of ultraviolet radiation on clearance rate of planktonic copepods with different photoprotective strategies.
}

\section{Cecilia Laspoumaderes ${ }^{1,2^{*}}$, Marcela Bastidas Navarro ${ }^{1}$, María Sol Souza ${ }^{1}$, Beatriz Modenutti $^{1}$ and Esteban Balseiro ${ }^{1}$}

1. Laboratorio de Limnología, INIBIOMA, CONICET-Universidad Nacional del Comahue, Quintral 1250, 8400 Bariloche, Argentina

2. Alfred-Wegener-Institut, Helmholtz-Zentrum für Polar- und Meeresforschung (AWI), Biologische Anstalt Helgoland, Postfach 180, 27498 Helgoland, Germany

*Corresponding author: claspoumaderes@comahue-conicet.gob.ar

Running title: Effect of UVR on copepod clearance rates

Keywords: UVR, oxidative stress, photoprotection plasticity, feeding rate, lake copepods.

\begin{abstract}
We studied two populations of Boeckella gracilipes and two populations of $B$. gibbosa that inhabit mountain lakes from North-Patagonian Andes with different optical properties. We combined field and laboratory experiments in order to determine the
\end{abstract}

This article has been accepted for publication and undergone full peer review but has not been through the copyediting, typesetting, pagination and proofreading process, which may lead to differences between this version and the Version of Record. Please cite this article as doi: 10.1002/iroh.201801960.

This article is protected by copyright. All rights reserved. 
effects of UVR on clearance rate among these taxa that had different UVR defences. The copepod populations differed in photoprotective compounds (carotenoids and mycosporine-like amino acids, MAAs) and antioxidant enzymes (glutathione Stransferase, GST). These variations were related to elevation, dissolved organic carbon content and the optical features of the inhabited lakes. Laboratory experiments showed a decrease in the CR in all populations exposed to UVR. Consistently, the long-term field experiment showed a negative impact of UVR on CR. We conclude that UVR exposure affects feeding, however, the magnitude of this negative effect depends on the exposure intensity and the photoprotective mechanisms employed by zooplankton.

\section{Introduction}

Ultraviolet radiation (UVR) is a naturally occurring biological stressor for many species living in aquatic ecosystems (Williamson 1995). Harmful effects of UVR result from the absorption of specific wavelengths by macromolecules (DNA, protein and chlorophyll), and from the interaction of UVR with dissolved substances in water, which forms a number of chemically reactive species and biologically toxic intermediates (Blough \& Zepp 1995; Perin \& Lean 2004). In transparent aquatic ecosystems UVR can penetrate deeply in the euphotic zone; therefore planktonic organisms have developed diverse protection strategies to deal with these hazardous wavelengths (Hansson et al. 2007; Hader et al. 2015).

Dissolved organic carbon (DOC) is considered a good predictor of UVR penetration in lakes (Morris et al. 1995). In particular, the coloured fraction CDOM (coloured dissolved organic matter), selectively removes the shorter wavelengths of solar

This article is protected by copyright. All rights reserved. 
radiation (Williamson \& Rose 2010). Therefore, when CDOM is elevated, an increase in survival and reproduction of UV-sensitive zooplankton species can be expected (Cooke et al. 2015). Lower zooplankton species richness is associated with higher seasonal variability of DOC (Shurin et al. 2010) and high lake transparency (Marinone et al. 2006). Changes in water transparency could be even more important for underwater UV exposure than changes in incidence solar radiation (Williamson et al. 1996).

In zooplankton, particularly calanoid copepods, the defence mechanisms against UVR include the accumulation of photoprotective compounds such as carotenoids or mycosporine-like aminoacids (MAAs) (Moeller et al. 2005; Hylander et al. 2009a), the induction of defence and repair enzymes such as glutathione reductase and glutathione Stransferase (GST) (Borgeraas \& Hessen 2000, 2002; Souza et al. 2010b) and, behavioural responses such as vertical migration (Fields et al. 2012; Fischer et al. 2015). Together these mechanisms may complement each other to reduce the effects of UVR exposure (Hansson et al. 2007).

The strategies for dealing with UV vary between organisms and are related to the environment they live in. The presence of photoprotective compounds, such as carotenoids, make copepods more susceptible to visual predators; therefore the acquisition of these compounds is an effective strategy to avoid photodamage in fishless lakes (Hansson et al. 2007; Hylander et al. 2014). Diel vertical migration requires energetic costs that can negatively affect growth and reproduction (Williamson \& Rose 2009) and is restricted to lakes that are deep enough relative to their transparency (Zagarese et al. 1997a). Additionally, the production of antioxidants and repair enzymes, occurs once the damage has already been done, and requires high nutritional demands

This article is protected by copyright. All rights reserved. 
(Balseiro et al. 2008). Hence, when UVR and predation threats are present simultaneously, animals are able to reduce photoprotective pigments and increase antioxidant enzymatic activities to generate an efficient defence strategy with a diminished predation risk (Hylander et al. 2012). In addition, copepods inhabiting shallow lakes are subject to fast and sudden changes in temperature and solar radiation (Hader et al. 2015) and to deal with these environmental conditions they can exhibit a phenotypic response in photoprotective pigment accumulation (Persaud et al. 2007; Souza et al. 2012). Different populations of the same species may differ greatly in the amount of photoprotective compounds and antioxidant defences depending on the features of lake they inhabit (Moeller et al. 2005). Furthermore, vertical migration is not always an available option for zooplankton, since shallow transparent lakes do not have a depth refuge (Zellmer et al. 2006).

UVR can also impose effects on copepod fitness, i.e. grazing. The few reported effects of UVR on feeding are contradictory; higher (Fields et al. 2011) or lower (Kouwenberg \& Lantoine 2007) grazing rates were observed when phytoplankton were exposed to UVR, and virtually nothing is known about the effects of UVR on feeding when only the grazer is exposed. Lacuna and Uye (2001) found that feeding of the marine copepod Acartia omorii was diminished by exposure to UV-B, but the feeding rates were indirectly determined by the gut pigmentation and no direct clearance rate was measured. Further research is needed to disentangle the complexity of responses of copepod grazing to UVR exposure (Gonçalves \& Hylander 2014).

Copepods inhabiting shallow transparent lakes are "trapped" in a water column with limited escape possibilities and lake features such as the CDOM content, the This article is protected by copyright. All rights reserved. 
presence of predators (e.g. fish) and elevation, influence the defence mechanisms employed by zooplankton. Surveys performed in Lakes from the European Alps and Patagonian Andes, show that copepods from higher elevation and higher UVR environments tend to have higher MAA and carotenoid contents (Tartarotti et al. 2001; Hessen 2003; Tartarotti et al. 2004). In this scenario, our main objective was to study the UVR effect on clearance rates in copepods with different photoprotective strategies. For this purpose, we studied two planktonic calanoid copepod species - Boeckella gracilipes and Boeckella gibbosa - that inhabit shallow mountain lakes, which differ in UVR penetration, fish presence and are located at different elevation in the Andes of NorthPatagonia. We sampled these species from four different lakes and experimentally evaluated the effects of UVR on feeding rates in these copepod populations from contrasting environments. We hypothesise that copepods feeding rates are negatively affected by UVR exposure. The photoprotection strategies employed by each population should be related to the features (i.e. depth, transparency) of the lake of origin, and hence lead to different sensitivities to UVR exposure among the populations. Therefore, we expect the magnitude of the negative effect of UVR on CR to depend on each populations' sensitivity to UVR that would be related to the environmental features of their lake of origin.

This article is protected by copyright. All rights reserved. 


\section{Methods}

Zooplankton

\section{Boeckella gibbosa}

B. gibbosa was studied in two small alpine lakes: Laguna Toncek $\left(41^{\circ} 12^{\prime} \mathrm{S}, 71^{\circ}\right.$ $29^{\prime} \mathrm{W}$ ) and Laguna Schmoll $\left(41^{\circ} 11^{\prime} \mathrm{S}, 71^{\circ} 30^{\prime} \mathrm{W}\right.$ ) (Table 1). Both lakes are nearby systems located in Mount Catedral, above the Nothofagus pumilio treeline (Bastidas Navarro et al. 2014). Both lakes are fishless and present a very simple zooplankton community dominated by coloured organisms, Boeckella gibbosa and the rotifer Hexarthra bulgarica (Modenutti 1993).

\section{Boeckella gracilipes}

We studied B. gracilipes from two lakes - Lake Verde $\left(41^{\circ} 15^{\prime} 37^{\prime \prime} \mathrm{S}\right.$ and $71^{\circ} 17^{\prime}$

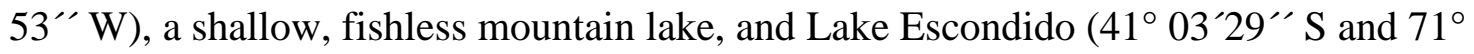
34' 20"), a comparatively deeper, piedmont lake containing fish (Table 1). Boeckella gracilipes is the dominant zooplankter in both lakes. However, in Lake Escondido the zooplankton structure is more complex, including cladocerans (Bosmina and Ceriodaphnia) and rotifers (Keratella, Polyarthra, etc.) (Balseiro \& Modenutti 1990; Bastidas Navarro \& Modenutti 2007) and the native fish Galaxias maculatus exerts a strong effect on the zooplankton community (Modenutti et al. 1993).

This article is protected by copyright. All rights reserved. 
Field sampling and laboratory UVR exposure experiments

Copepods were collected in summer on sunny windless days (Lake Verde 01/18/2010; Lake Escondido 01/20/2011; and Lakes Schmoll and Toncek on 02/16/2011) with a $25 \mathrm{~cm}$ diameter and $55 \mu \mathrm{m}$ mesh size plankton net. We made 2-3 vertical tows, from the depth of maximum copepod abundance to the surface, in the central area of each lake. The tows were pooled in the same container to eliminate potential variance among tows. In Lake Escondido samples were taken from 6-7 m depth (maximum copepod abundance at 5-6 m, 1.5 ind. $\mathrm{L}^{-1}$ (Balseiro \& Modenutti 1990), in Lake Toncek from $10 \mathrm{~m}$ depth (maximum copepod abundance at 7.5m (Marinone et al. 2006)). In Lake Verde and Schmoll, we checked the vertical distribution of copepods by taking three samples from different depths. We found no clear copepod vertical distribution and hence copepods were sampled from $4 \mathrm{~m}$ depth in Lake Verde and $2.5 \mathrm{~m}$ in Lake Schmoll. Then, animals were immediately transported to the laboratory in thermally insulated containers filled with natural lake water. Water samples of $5 \mathrm{~L}$ were collected with a Ruttner bottle at the same depth as the copepods, and immediately transported to the laboratory. Lake water was filtered through precombusted GF/F filters (Whatman) and a volume of $100 \mathrm{~mL}$ was designated for dissolved organic carbon (DOC) quantification with a Shimadzu TOC VCSH and for spectrophotometric scans carried out with a double beam spectrophotometer (Shimadzu UV2450).

The water colour from each lake was estimated using $a_{440}$ parameter considering the absorbance at $440 \mathrm{~nm}$ in a $10 \mathrm{~cm}$ cuvette as described by Pace and Cole (2002). Samples were read against a blank prepared from MilliQ water. Colour was expressed as a wavelength specific absorption coefficient in units of inverse metres.

This article is protected by copyright. All rights reserved. 


$$
a_{440}=\frac{\operatorname{Ln}\left(10^{A_{440}}\right)}{l}
$$

Where, $A_{440}$ is the absorbance at $440 \mathrm{~nm}$ and $l$ the cell path length in $\mathrm{m}$.

This parameter $\left(a_{440}\right)$, reflects the content of light-absorbing, primarily humic material in the water (i.e. CDOM) (Table 1). Experiments were conducted in water from the corresponding lake; thus, the remaining volume of filtered lake water was used for this purpose. Light attenuation coefficients $\left(\mathrm{K}_{\mathrm{d}}\right)$ were estimated from the vertical light profiles of each lake with a PUV 500B submersible radiometer (PUV 500B; Biospherical Instruments, San Diego, CA, USA) as the slope of $\log _{\mathrm{e}}$ transformed irradiance data with depth.

Experiments and biochemical determinations were carried out with non-ovigerous females of B. gracilipes from Lakes Verde and Escondido, and CIV and CV of B. gibbosa from Lakes Toncek and Schmoll. In these two lakes, B gibbosa has a synchronic life cycle and adults appear in the lake in early spring and autumn, and spend the summer as CIV and CV (Modenutti 1993). Size-matched, non-injured individuals of each copepod species were selected under a stereomicroscope. In the case of B. gibbosa, we put equal amounts of each stage (CIV and CV) in each replicate for the experiments and biochemical determinations. These instars were identified under a stereomicroscope according to Chapman and Burns (1976). Individuals from each lake were immediately separated for determination of carotenoids, MAAs concentrations and GST activity (see below). Copepod abundances were quantified under stereomicroscope.

This article is protected by copyright. All rights reserved. 
We experimentally exposed each copepod population to UVR and then analysed feeding rates. Non-injured individuals were selected under a stereomicroscope, rinsed with filtered lake water and transferred to $60 \mathrm{~mL}$ quartz flasks filled with filtered lake water. The flasks were placed $30 \mathrm{~cm}$ from a light source for $4 \mathrm{~h}$ in an incubator at $15 \pm$ $1^{\circ} \mathrm{C}$. This temperature corresponds to the hypolimnion of Lake Escondido (epilimnion $23^{\circ} \mathrm{C}$ ) and the epilimnion of Lake Toncek (hypolimnion $7^{\circ} \mathrm{C}$ ). In lakes Verde and Schmoll, no stratification occurs and during summer days (as the study dates) temperature reaches $15^{\circ} \mathrm{C}$. The exposure time of our experiments was determined in a previous study to ensure the detection of sublethal effects of UV on copepods (Souza et al. 2010a). Animals were exposed to two different light treatments: 1)- only photosynthetically active radiation (PAR) or 2)- PAR + UVR. Light was provided by two fluorescent UVA-340 lamps (Q-Panel Lab Products, Cleveland, OH, U.S.A.), two fluorescent daylight lamps (Phillips TLT $40 \mathrm{~W}$ daylight) (PAR) and two fluorescent black-light lamps with maximum emission at $380 \mathrm{~nm}$ (Phillips TL-D $30 \mathrm{~W} / 08$ ) to cover the gap between the UVA-340 and daylight lamps. During this incubation, experimental units received $35 \mu \mathrm{W} \mathrm{cm} \mathrm{nm}^{-1}$ of the $340 \mathrm{~nm}$ wavelength, $4 \mu \mathrm{W} \mathrm{cm}{ }^{-2} \mathrm{~nm}^{-1}$ of the 305 $\mathrm{nm}$, and $98 \mu \mathrm{mol}$ photons $\mathrm{m}^{-2} \mathrm{~s}^{-1}$ of PAR (400-700 nm). These UV irradiance levels are equivalent to ground level noon summer sunlight in the area (Fig. 1 a) (Souza et al. 2010a) and doses are equivalent to $4 \mathrm{hr}$ exposure in the field (Table 2). To prevent any output less than $290 \mathrm{~nm}$, the UVA lamps were wrapped with acetate film. The PAR treatment was produced using cut-off filters to remove wavelengths shorter than $400 \mathrm{~nm}$ with Courtgard $^{\mathrm{TM}}$ (CPFilms Inc., Martinsville, VA, USA) a long-wave pass plastic that transmits 95\% of PAR, while blocking all UV-B and transmitting only 9\% of UV-A in

This article is protected by copyright. All rights reserved. 
water (Doyle et al. 2005; Leach et al. 2015). In the experiments with B. gracilipes we performed 5 replicates of each treatment, while with B. gibbosa we performed 3 replicates (each replicate consisted of 10 individuals per $60 \mathrm{~mL}$ quartz flask). At the end of incubation, each replicate was immediately transferred to the feeding experiment (see below). During the UVR/ PAR laboratory experiments no copepod mortality was observed.

\section{Laboratory feeding experiments}

Immediately after the $4 \mathrm{~h}$ of PAR or UVR exposure, copepods were transferred to $60 \mathrm{~mL}$ quartz flasks filled with a Chlamydomonas reinhardtii culture with approximately 5000 cells $\mathrm{mL}^{-1}(4989 \pm 24)$. C. reinhardtii was maintained in chemostats under laboratory conditions in Marine Biological Laboratory medium (MBL) (Guillard \& Lorenzen 1972) at $15 \pm 1^{\circ} \mathrm{C}$ and $98 \mu \mathrm{mol}$ photons $\mathrm{m}^{-2} \mathrm{~s}^{-1}$. C. reinhardtii abundances were determined by filtering $20 \mathrm{~mL}$ onto $1 \mu \mathrm{m}$ polycarbonate black membrane filters and later quantified with an epifluorescence microscope using the natural autofluorescence of chlorophyll under blue filters (U-MWB filter). A control treatment was run under identical conditions but without the addition of the copepods to check for changes in cell abundance during the experiments. The flasks were placed in a device that half-rotated the containers every 2 min. The entire device was maintained in a dark incubator at $15 \pm$ $1^{\circ} \mathrm{C}$ for $4 \mathrm{~h}$.

CR were calculated with Gauld’s formula (Gauld 1951) modified by Edmondson and Winberg (1971):

This article is protected by copyright. All rights reserved. 


$$
C R=V \frac{\ln C_{c}-\ln C_{t}}{t \cdot N}
$$

where $V$ is the flask volume in $\mathrm{mL}, t$ is the time in hours during which the animals fed, $N$ is the number of animals, $C_{c}$ is the control cell concentration and $C_{t}$ is the treatment cell concentration. Final control (Cc) was used instead of initial concentration (Gauld 1951), to account for changes in cell concentration during the feeding experiment (Edmondson \& Winberg 1971)

\section{Field incubation and field feeding experiment}

We also performed a field experiment with two main purposes; 1) To evaluate whether field UV irradiances cause similar effects to laboratory UV irradiances, and 2) to evaluate the long-term (one week) effect of UVR on feeding in a copepod population with relatively high resistance to UVR. We carried out the experiments with $B$. gracilipes in Lake Verde and used natural phytoplankton for the determination of in situ clearance rates. This experiment was also conducted in early summer in $10 \mathrm{~L}$ polypropylene bags and consisted of one-week incubation that began on January $25^{\text {th }}, 2011$. We used two contrasting light treatments: full solar radiation (UVR) and PAR radiations only (PAR). The PAR treatment was produced using the same filters as in the laboratory experiments. Full solar radiation treatment was obtained using polypropylene bags transparent to UVR. Before the experiments, we checked the polypropylene for UV transparency with 290$700 \mathrm{~nm}$ spectra scanning with a double beam spectrophotometer (Shimadzu UV2450, Japan).

This article is protected by copyright. All rights reserved. 
The bags ( 5 enclosures per treatment) were filled with lake water, collected at the same depth as the copepods, that was previously filtered with an $80 \mu \mathrm{m}$ mesh net. One hundred copepods obtained directly from the lake were added to each container to reach a final concentration approximately double that of the lake. The enclosures were incubated at 0.1 m below the surface (corresponding to $77 \%$ and $80 \%$ of $305 \mathrm{~nm}$ and $320 \mathrm{~nm}$ surface radiation respectively, see Fig. $1 \mathrm{~b}$ for proportion of surface irradiance that penetrates the water column) for one week. The exposure time of our experiments was determined according to Zagarese et al. (1997b) and Souza et al. (2010b). Underwater irradiance was logged with a submersible radiometer (PUV 500B, Biospherical Instruments, CA). After the one-week exposure, the water from each container was gently filtered through a 200 $\mu \mathrm{m}$ plankton net. Copepods were recovered and ten individuals were used for feeding experiments.

Ten copepods from each replicate of each treatment were transferred to $60 \mathrm{~mL}$ quartz flasks filled with natural lake water that was filtered through an $80 \mu \mathrm{m}$ mesh net. The flasks were incubated under the same light conditions as the previous field incubation (i.e., UVR or PAR treatment). Control treatments were run under identical conditions but without the addition of copepods. At the end of the experiment, all replicates of the feeding experiments and controls were fixed with acid Lugol's solution. In the laboratory, the different phytoplanktonic cells were identified and the cell concentrations were estimated with an inverted microscope (Olympus IX70) at $1000 \mathrm{x}$ magnification. Cell counts were carried out for each phytoplanktonic species, and CR was estimated for each species and calculated for the entire phytoplanktonic assemblage.

This article is protected by copyright. All rights reserved. 


\section{Laboratory determinations}

Total carotenoid and MAAs concentration were spectrophotometrically estimated in five replicates of 30 individuals each, which were first placed in filtered (GF/F) lake water for $2 \mathrm{~h}$ for gut evacuation. Carotenoids were extracted in ethanol (95\%) and quantified in the supernatant using a spectrophotometer (double beam Shimadzu UV2450) at $474 \mathrm{~nm}$, which is the absorption peak for common carotenoids in copepods (Hylander et al. 2009b). The absorbance was also scanned from 300 to $790 \mathrm{~nm}$, and no peaks were observed at the absorption maximum of chlorophyll $a$ (665 nm), indicating that gut evacuation had been effective and that chlorophyll did not interfere with the results. MAAs concentrations were estimated by spectrophotometry following compounds extraction protocols of Tartarotti and Sommaruga (2002) and Hylander and Hansson (2013). MAAs were extracted in 25\% (v/v) aqueous methanol by incubating overnight at $4^{\circ} \mathrm{C}$ and then in a water bath at $45^{\circ} \mathrm{C}$ for $2.5 \mathrm{~h}$. Extracts were then centrifuged (5000 x g) and the supernatant was analysed through spectrophotometric scans (250 to $790 \mathrm{~nm}$ ) in $1 \mathrm{~cm}$ quartz cuvettes using a double-beam spectrophotometer (Shimadzu UV2450). MAAs concentration was estimated as the sum of absorbance in the 308-370 nm range normalised by the extraction volume and dry mass.

Glutathione S-transferase activity (GST) was also determined in the copepods from each lake. Copepods were homogenized using a glass-Teflon homogenizer with ice-cold $50 \mathrm{mM}$ potassium phosphate buffer, $\mathrm{pH} 7.7$ containing $1 \mathrm{mM}$ EDTA and $0.1 \%$ Triton X100 (Borgeraas \& Hessen 2000, 2002). Homogenates were centrifuged at 10,000 x g and $4^{\circ} \mathrm{C}$ for 10 minutes and supernatants used as enzyme sources. The enzyme activity of three sub-samples was determined with a minimum of two measurements per sub-sample

This article is protected by copyright. All rights reserved. 
GST activity was determined at $25^{\circ} \mathrm{C}$ by using $100 \mathrm{mM}$ phosphate buffer $(\mathrm{pH}=6.5)$ with $1 \mathrm{mM}$ of 1-chloro-2,4-dinitrobenzene (CDNB) in acetonitrile (1\% v/v) and $1.2 \mathrm{mM}$ glutathione GSH as substrates (Habig et al. 1974). GST activity was then assessed as the absorbance at $340 \mathrm{~nm}$ after two minutes. The specific activity of GST was expressed in nanomoles of product developed per minute per mg of protein (nmol prod. min. ${ }^{-1} \mathrm{mg}$ $\operatorname{prot}^{-1}$ ) at saturating substrate concentrations. Linearity of the reaction with protein quantity per assay was determined $\left(r^{2}=0.975\right)$.

Protein determination was performed according to Lowry et al. (1951) with bovine serum albumin as a standard. The protein quantity per assay was $7.32 \pm 0.08 \mu \mathrm{g}$ proteins per reaction for GST activity.

\section{Data analysis}

Results are expressed as the mean \pm standard error. We used a Student's $t$-test for independent samples to compare Carotenoids, MAAS content, and GST activity between populations of the same species, and for comparisons of the mean CR between PAR and UVR for laboratory and field experiments within each population. To directly compare the importance of UVR across the four lakes, the response of interest was the relative difference in CR between treatments within each lake. For this purpose, we calculated the effect size (ES) as Cohen's $d$ and the 95\% Confidence Interval (CI $\left.{ }_{95 \%}\right)$ of each experiment. The $E S$ provides a metric that can be used for comparisons across lakes (Leach et al. 2015) and its calculated as the difference between the mean CR in each treatment expressed as a proportion of the pooled standard deviation (Cumming et al. 2013). All analyses were performed in Sigma Stat 4.1 software for Windows.

This article is protected by copyright. All rights reserved. 


\section{Results}

\section{Lake features}

The four lakes differ greatly in their optical characteristics (Table 1). Lakes Schmoll and Toncek inhabited by B. gibbosa, are both located above the treeline. Both lakes are highly transparent, however Lake Schmoll is shallower and has lower $\mathrm{K}_{\mathrm{d}}, a_{440}$, and DOC than Lake Toncek (Table 1). As a result of the high transparency of these two lakes, all or most of their water volume is exposed to direct UVR, without a depth water refuge for zooplankton (Table 1). Lakes Verde and Escondido are both located below the treeline. Lake Verde is a transparent shallow lake; however, it has a higher DOC concentration than the previous two lakes (Schmoll and Toncek), and hence a more significant fraction of the lake volume is protected from direct UVR (Table 1). Lake Escondido is located at the lowest elevation, is deeper than Verde and has the highest DOC concentration, which provides protection against the direct incidence of $\mathrm{UV}_{320 \mathrm{~nm}}$, as this wavelength only penetrates the first $0.6 \mathrm{~m}$ of the water column (Table 1). Spectrophotometric scans of Lake Escondido showed higher maximum absorption values than Lake Verde, particularly in the ultraviolet and violet-blue end of the spectra (Fig. 2). In Lake Escondido, the contribution of dissolved substances at lower wavelengths was large with $a_{440}=2.003 \mathrm{~m}^{-1}$, being considerably higher than for Lake Verde $\left(a_{440}=0.253\right.$ $\mathrm{m}^{-1}$, Table 1).

Photoprotective strategies found in the field

We found significant differences in UV defence strategies not only between both copepod species but also within populations of the same species (Table 3). Both

This article is protected by copyright. All rights reserved. 
populations of B. gibbosa were highly pigmented. Animals from Lake Toncek had higher total carotenoid concentrations than those from Lake Schmoll (Table 3, $t_{(8)}=3.55, p=$ 0.024). In contrast, MAAs concentrations were significantly higher in copepods from Lake Schmoll than in those from Lake Toncek (Table 3, $t_{(8)}=3.23, p=0.032$ ). On the other hand, B. gracilipes from Lake Verde and Lake Escondido differed greatly in the amount of photoprotective compounds. Copepods from Lake Verde were highly pigmented and presented high MAAs concentration, while both photoprotective compounds were undetectable in the population from Lake Escondido (Table 3).

Glutathione S-transferase activity was higher in B. gibbosa than in B. gracilipes (Table 3, $t_{(10)}=3.08, p=0.011$ ). However, there were also intraspecific differences. $B$. gibbosa from Lake Schmoll showed higher GST activity than the Toncek population (Table 3, $t_{(4)}=3.54, p=0.017$ ) whereas B. gracilipes from Lake Verde had higher GST activity than animals from Lake Escondido (Table 3, $t_{(4)}=3.09, p=0.036$ ).

\section{Effects of UVR on clearance rates}

We found a decrease in clearance rates after UVR exposure in the four copepod populations ( $p<0.05$, all cases tested). The strength of the effect (ES) differed between populations of the same species inhabiting different lakes (Fig. 3). During laboratory exposure experiments we used lake water with different CDOM content. Due to these differences, B. gracilipes from Lake Escondido received approximately 0.8 of the UVR compared to the copepods from Lake Verde ( $85 \%$ of the $320 \mathrm{~nm}$ band and $83 \%$ of the $305 \mathrm{~nm}$ band). The CR of B. gracilipes from both lakes was lower after the UVR exposure in comparison to the PAR treatment (Lake Verde: $t_{(8)}=3.49, p=0.008$; Lake

This article is protected by copyright. All rights reserved. 
Escondido: $t_{(8)}=13.58, p<0.001$ ) (Fig. 3 a and b). However, the negative effect of UVR on CR was stronger for the population of B. gracilipes from Lake Escondido (ES= 8.59, $\left.C I_{95 \%}=4.6-12.55\right)$ than for the population of Lake Verde $\left(E S=2.20, C I_{95 \%}=0.63-3.78\right)$.

On the contrary, Lakes Toncek and Schmoll have low CDOM content; thus, both populations of B. gibbosa received almost the same UV doses (copepods from Toncek received $99 \%$ of $320 \mathrm{~nm}$ and $98 \%$ of $305 \mathrm{~nm}$ of that received by Schmoll individuals). $B$. gibbosa from Lake Schmoll and Lake Toncek also showed a negative effect of UVR on CR (Lake Schmoll: $t_{(4)}=3.13, p=0.035$; Lake Toncek: $\left.t_{(4)}=38.74, p<0.001\right)$ (Fig. 3 c and d). However, the strength of UVR effect on CR differed between populations, since the $E S$ was higher for Lake Toncek $\left(E S=7.14, C I_{95 \%}=2.80-11.49\right)$ than for Lake Schmoll $\left(E S=2.55, C I_{95 \%}=0.39-4.69\right)$. Therefore, $B$. gibbosa from Lake Toncek resulted with a higher UVR sensitivity on CR.

In the field experiment, we also found a decrease in clearance rates with natural phytoplankton when copepods were exposed to UVR (Fig. 3 e) $\left(t_{(16)}=4.61, p<0.001\right)$. These results supported those obtained in the laboratory experiments, though food composition differed (Table 4). In this case, food was natural phytoplankton constituted mainly by nanoflagellate cells and the dominant species Chrysochromulina parva and Plagioselmis lacustris were cleared at the highest rates (Table 4). Regardless of the experimental differences, the strength of the negative effect of UVR on CR did not differ between the laboratory experiment and the field experiment carried out with B. gracilipes from Lake Verde (Laboratory experiment: $E S=2.20, C I_{95 \%}=0.63-3.78$; Field Experiment: $\left.E S=2.18, C I_{95 \%}=1.01-3.35\right)$.

This article is protected by copyright. All rights reserved. 


\section{Discussion}

We studied the effect of UVR on the clearance rates of copepods from contrasting mountain lakes. We show how copepods inhabiting lakes from North-Patagonian Andes are able to adjust different defence mechanisms to deal with high and potential hazardous UVR, which results from the additive effects of the lack of aerial pollutants (Mladenov et al. 2011), high elevation, low CDOM content (Morris et al. 1995), and the proximity to the ozone depletion area (Villafañe et al. 2001). We found that populations of the same species differ greatly in photoprotective compound contents and enzyme activities as a response to the environmental conditions. High elevation and latitude environments are predicted to be the most affected by global change (IPCC 2014) with consequences on lake water transparency. For example, increasing temperature promotes thermal stability reducing mixing and increasing lake transparency (Williamson et al. 2009). Glacier retreat modifies the hydrological connectivity and changes the penetration of UVR in lake water (Laspoumaderes et al. 2017). CDOM content of lakes with forested watersheds, is closely related to precipitation intensity and frequency (Bishop et al. 2004; Bastidas Navarro \& Modenutti 2012). All these changes may play a central role in the ecology of aquatic communities.

B. gracilipes seems to be a plastic species with an unpigmented population in Lake Escondido and a highly-protected one in Lake Verde. Lake Escondido provides zooplankton with a UVR depth refuge, because only the first $0.6 \mathrm{~m}$ of the water column is penetrated by UVR (320 nm band). Therefore, photoprotective pigments seem not to be necessary in this population. The planktonic assemblage in Lake Escondido is more complex than on the other lakes, and has a clear spatial heterogeneity in phytoplankton

This article is protected by copyright. All rights reserved. 
and rotifer distribution (Bastidas Navarro \& Modenutti 2007). On the other hand, in Lake Escondido copepods are exposed to predation by planktivorous fish. Hence, the lack of pigments provides an advantage to avoid visual predators. On the contrary, Lake Verde is a transparent fishless lake with relatively high UV penetration. In this lake, the copepod population had high carotenoids and MAAs concentrations and GST activity, in order to obtain a high UVR protection without the risk of being eaten. The zooplankton community of Lake Verde is less complex than in Lake Escondido (only copepods and rotifers), and the combination of environmental conditions (absence of fish) and the species features (lower sensitivity to UVR) seem to be optimal in this lake as copepod abundance is the highest of the four studied populations with 36 ind. $\mathrm{L}^{-1}$.

The two populations of $B$. gibbosa are pigmented with high carotenoids, MAAs and GST activity. Lake Toncek and Schmoll are fishless, so the risk of visual predation is absent and copepods are not in a trade-off between UVR and visual predation. Nevertheless, organisms are exposed to high UVR penetration because both lakes are located above the treeline and are extremely transparent (Bastidas Navarro et al. 2014). Interestingly, we observed differences in the photoprotective strategies. Carotenoid content was slightly higher in copepods from Lake Toncek. Carotenoids protect against photo-oxidative damage but their UVR-screening capability is limited because they absorb mainly in the blue region (Sommaruga 2010). In Lake Schmoll B. gibbosa had higher GST activity and higher MAAs content than in Lake Toncek. MAAs offer more effective photoprotection than carotenoids due to their high efficiency in transforming UVR energy into heat without significant negative effects on the organism (Moeller et al. 2005). This difference can be due to the fact that copepods from Lake Toncek can avoid

This article is protected by copyright. All rights reserved. 
the first meters of the water column with a maximum abundance at $7.5 \mathrm{~m}$ during day and $6.4 \mathrm{~m}$ at night (Marinone et al. 2006), thus, reducing their direct exposure to UVR. According to the present study this copepod population would receive only 2\% of the 320 nm wavelength during the day. On the contrary, in Lake Schmoll 65 and $60 \%$ of the surface 320 and $305 \mathrm{~nm}$, respectively, reach the bottom, so this lake has no depth refuge against UVR. B. gibbosa is exposed to high UVR with MAAs as the main photoprotective pigment. The zooplankton assemblage of these two lakes is simple. It is composed mainly of B. gibbosa and Hexarthra bulgarica and it is free of cladoceran competition. In Lake Toncek B. gibbosa develops from early copepodids to adults between December and March, with an abundance of 20-30 ind. $\mathrm{L}^{-1}$. H. bulgarica appears in late January, and is controlled mainly by B. gibbosa predation (Modenutti 1993). In Lake Schmoll, although the zooplankton assemblage is similar, abundances are much lower than in Lake Toncek (2.6 ind. $\mathrm{L}^{-1}$ ) (Guerrero 1993; Zagarese et al. 2000). The ability to accumulate high amounts of photoprotective compounds, combined with an increase in GST activity, probably allows this species to colonize harsh environments such as the alpine lake Schmoll with extremely low CDOM shield, although in lower abundances.

Possible differences in life-stage specific enzyme activities, contents of photoprotective compounds or clearance rates should be taken into account, as we used adults of B. gracilipes and CIV and CV of B. gibbosa. We lack information on changes of GST activity with ontogeny. However, previous studies that analysed ontogenetic trends in photoprotective compounds found no differences in MAAs concentration between these life stages (Tartarotti \& Sommaruga 2006). Lotocka and Styczynska-

This article is protected by copyright. All rights reserved. 
Jurewicz (2001) and Lotocka et al. (2004) found an ontogenetic gradual increase in carotenoid contents but they pooled together CIV, CV, and adults as the last ontogenetic stage. Small differences in the yellow carotenoids but not in the red ones were found in Eudiaptomus gracilis but not in Diaptomus castor when comparing all juvenile stages pooled together versus adults (Brüsin et al. 2016). Hence, it is not likely that the difference in photoprotective compounds between our populations are life-stage related. Furthermore, absolute clearance rates might have been affected by life stage, but we used the same life stage composition for each species and the focus was on the size effect of UVR on CR and not on absolute CR values.

Independent of the photoprotective strategy, we observed a decrease in CR under UVR exposure in all laboratory and field experiments (Fig. 3). However, the strength of the negative effect of UVR on CR was related to the photoprotective strategy of each copepod population. In B. gibbosa the two populations are well protected. However, the population of Lake Toncek has lower GST activity and MAAs content than that from Lake Schmoll. This condition was reflected in the larger ES obtained for Toncek in the CR experiment. In the laboratory, under the PAR treatment, the CR of the four studied populations did not differ substantially, except for B. gibbosa from Lake Schmoll that showed lower CR than the others. The lower CR of B. gibbosa from Lake Schmoll can be attributed to the fact that copepods coming from this harsh environment are chronically affected by UVR. Environmental features in this lake are extreme, and copepod abundance is much lower than in Lake Toncek. Hence, B. gibbosa is able to live in this habitat but it might be under constant stress. This chronic stress condition probably affected the performance of B. gibbosa in the laboratory. On the other hand, B. gibbosa

This article is protected by copyright. All rights reserved. 
has a photorepair mechanism to deal with UVR damage (Zagarese et al. 1997a). As we carried out the CR experiments in the dark right after the UVR incubation, these copepods had no chance of photoreactivation. However, only the CR of B. gibbosa from Lake Schmoll differed from the other populations and if the lack of photorepair was responsible for the low $\mathrm{CR}$, we should have observed the same result with the population of Lake Toncek. In B. gracilipes the strongest effect was observed in the population from Lake Escondido. The population of B. gracilipes from this lake has low GST activity and undetectable carotenoids and MAAs contents. Hence, when this population is exposed to UVR without escape possibilities as in the laboratory experiment, we observed high ES.

The CR decrease with UVR exposure was consistent for B. gracilipes when using either a single algal prey (laboratory experiments) or natural phytoplankton (field experiment) or if food was exposed or not to UVR. In the laboratory experiments, only copepods were exposed to UVR but not their food. On the contrary, in the field experiment, natural phytoplankton cells were exposed always to the same conditions as those of copepods. The responses of aquatic animals to UV radiation are highly dependent on the spectral composition of the source, its intensity, and the exposure duration. Because of differences in spectral composition and exposure duration we determined the magnitude of the differences (Cohen's ES) to make these two types of experiments more comparable (Sullivan \& Feinn 2012). In the field experiment with $B$. gracilipes we obtained a similar ES on CR than in the laboratory. However, we expected a stronger effect of UVR on CR for the field experiment, as a consequence of the higher and longer UVR exposure (one week) to natural solar irradiances without a depth water refuge available. However, in this experiment, not only copepods, but also phytoplankton

This article is protected by copyright. All rights reserved. 
cells were exposed to damaging UVR; in fact mixotrophic nanoflagellates are negatively affected by UVR (Bastidas Navarro et al. 2011). Hence, this negative effect on food cells might have, at least partially, compensated for the negative effect of the longer exposure to UVR (Fields et al. 2011).

In conclusion, UVR has a negative impact on copepod clearance rate. Differential use of the photoprotective mechanisms would have an impact on the life history traits of these zooplankters, with unclear consequences on food web interactions. A large number of studies document substantial impacts of solar UV radiation on individual species, yet considerable uncertainty remains with respect to assessing impacts on ecosystems. Increased transparency would lead to lower feeding rates of copepods with a consequent fitness decrease. One should expect lower feeding rates in copepods to lead to positive changes in the prey. However, the impacts of enhanced levels of UVR on aquatic ecosystems are complex and simple responses are not likely the rule.

\section{Acknowledgements}

We thank the Delegación Regional Patagonia of the Administración de Parques Nacionales for granting permission to collect material for this study. This work was supported by Fondo Nacional de Ciencia y Técnica PICT 2014-1002, 2015-0418 and 2015-2138. All authors are CONICET researchers and C.L is an Alexander von Humboldt Research Fellow at Alfred Wegener Institute, Helgoland.

This article is protected by copyright. All rights reserved. 


\section{References}

Balseiro, E. G. \& Modenutti, B. E. 1990: Zooplankton dynamics of Lake Escondido (Rio Negro, Argentina), with special reference to a population of Boeckella gracilipes (Copepoda, Calanoida). Internationale Revue der Gesamten Hydrobiologie, 75, 475-491.

Balseiro, E. G., Souza, M. S., Modenutti, B. E. \& Reissig, M. 2008: Living in transparent lakes: Low food P:C ratio decreases antioxidant response to ultraviolet radiation in Daphnia. Limnology and Oceanography, 53, 2383-2390.

Bastidas Navarro, M., Balseiro, E. \& Modenutti, B. 2014: Bacterial community structure in patagonian Andean Lakes above and below timberline: from community composition to community function. Microbial Ecology, 68, 528-541.

Bastidas Navarro, M., Balseiro, E. G. \& Modenutti, B. E. 2011: UV radiation simultaneously affects phototrophy and phagotrophy in nanoflagellate-dominated phytoplankton from an Andean shallow lake. Photochemical \& Photobiological Sciences, 10, 1318-1325.

Bastidas Navarro, M. \& Modenutti, B. 2007: Effect of macrophytes and food resources on the horizontal distribution of testate amoebae and rotifers in an AndeanPatagonian lake. Revista chilena de historia natural, 80, 345-362.

Bastidas Navarro, M. \& Modenutti, B. 2012: Precipitation patterns, dissolved organic matter and changes in the plankton assemblage in Lake Escondido (Patagonia, Argentina). Hydrobiologia, 691, 189-202.

Bishop, K., Köhler, S., Cory, N. \& Laudon, H. 2004: Riparian Zone Controls on the Chemical Dynamics of DOC-Rich Runoff from a Boreal Hillslope. In: AGU Fall Meeting Abstracts.

Blough, N. V. \& Zepp, R. G. 1995: Reactive oxygen species in natural waters. In: Active oxygen in chemistry. Springer, pp. 280-333.

This article is protected by copyright. All rights reserved. 
Borgeraas, J. \& Hessen, D. O. 2000: UV-B induced mortality and antioxidant enzyme activities in Daphnia magna at different oxygen concentrations and temperatures. Journal of Plankton Research, 22, 1167-1183.

Borgeraas, J. \& Hessen, D. O. 2002: Variations of antioxidant enzymes in Daphnia species and populations as related to ambient UV exposure. Hydrobiologia, 477, 15-30.

Brüsin, M., Svensson, P. A. \& Hylander, S. 2016: Individual changes in zooplankton pigmentation in relation to ultraviolet radiation and predator cues. Limnology and Oceanography, 61, 1337-1344.

Chapman, M. A. \& Burns, C. W. 1976: Sexual and other differences in copepodite stages of some New Zealand Calamoecia and Boeckella spp.(Copepoda: Calanoida). New Zealand Journal of Marine and Freshwater Research, 10, 131-137.

Cooke, S. L., Fischer, J. M., Kessler, K., Williamson, C. E. et al. 2015: Direct and indirect effects of additions of chromophoric dissolved organic matter on zooplankton during large-scale mesocosm experiments in an oligotrophic lake. Freshwater Biology, 60, 2362-2378.

Cumming, G. S., Ndlovu, M., Mutumi, G. L. \& Hockey, P. A. R. 2013: Responses of an African wading bird community to resource pulses are related to foraging guild and food-web position. Freshwater Biology, 58, 79-87.

Doyle, S. A., Saros, J. E. \& Williamson, C. E. 2005: Interactive effects of temperature and nutrient limitation on the response of alpine phytoplankton growth to ultraviolet radiation. Limnology and Oceanography, 50, 1362-1367.

Edmondson, W. T. \& Winberg, G. G. 1971: A manual on methods for the assessment of secondary productivity in fresh waters. In: IBP Handbook. Blackwell Scientific Publications Oxford.

This article is protected by copyright. All rights reserved. 
Fields, D. M., Durif, C. M. F., Bjelland, R. M., Shema, S. D. et al. 2011: Grazing Rates of Calanus finmarchicus on Thalassiosira weissflogii Cultured under Different Levels of Ultraviolet Radiation. PLoS ONE, 6, e26333.

Fields, D. M., Shema, S. D., Browman, H. I., Browne, T. Q. et al. 2012: Light primes the escape response of the Calanoid Copepod, Calanus finmarchicus. PLoS ONE, 7.

Fischer, J. M., Olson, M. H., Theodore, N., Williamson, C. E. et al. 2015: Diel vertical migration of copepods in mountain lakes: The changing role of ultraviolet radiation across a transparency gradient. Limnology and Oceanography, 60, 252262.

Gauld, D. T. 1951: The grazing rate of planktonic copepods. Journal of the Marine Biological Association of the United Kingdom, 29, 695-706.

Gonçalves, R. \& Hylander, S. 2014: Marine copepods and solar radiation. In: Copepods: Diversity, Habitat and Behavior. Nova Science Publishers, Incorporated.

Guerrero, C. 1993: Estudio demográfico de Pseudoboeckella gibbosa Brehm (Copepoda, Calanoida) en un lago de altura de los Andes Australes. Centro Regional Universitario Bariloche, Universidad Nacional del Comahue, Argentina.

Guillard, R. R. L. \& Lorenzen, C. J. 1972: Yellow-green algae with chlorophyllide $c$. Journal of Phycology, 8, 10-14.

Habig, W. H., Pabst, M. J. \& Jakoby, W. B. 1974: Glutathione S transferases. The first enzymatic step in mercapturic acid formation. Journal of Biological Chemistry, 249, 7130-7139.

Hader, D. P., Williamson, C. E., Wangberg, S. A., Rautio, M. et al. 2015: Effects of UV radiation on aquatic ecosystems and interactions with other environmental factors. Photochemical and photobiological sciences 14, 108-126.

This article is protected by copyright. All rights reserved. 
Hansson, L.-A., Hylander, S. \& Sommaruga, R. 2007: Escape from UV threats in zooplankton: a cocktail of behavior and protective pigmentation. Ecology, 88, 1932-1939.

Hessen, D. O. 2003: UVR and pelagic metazoans. UV effects in aquatic organisms and ecosystems, 1, 399.

Hylander, S., Boeing, W. J., Granéli, W., Karlsson, J. et al. 2009a: Complementary UV protective compounds in zooplankton. Limnology and Oceanography, 54, 18831893.

Hylander, S., Grenvald, J. C. \& Kiørboe, T. 2014: Fitness costs and benefits of ultraviolet radiation exposure in marine pelagic copepods. Functional Ecology, 28, 149-158.

Hylander, S. \& Hansson, L.-A. 2013: Vertical distribution and pigmentation of Antarctic zooplankton determined by a blend of UV radiation, predation and food availability. Aquatic Ecology, 47, 467-480.

Hylander, S., Larsson, N. \& Hansson, L. A. 2009b: Zooplankton vertical migration and plasticity of pigmentation arising from simultaneous UV and predation threats. Limnology and Oceanography, 54, 483-491.

Hylander, S., Souza, M. S., Balseiro, E. G., Modenutti, B. E. et al. 2012: Fish-mediated trait compensation in zooplankton. Functional Ecology, 26, 608-615.

IPCC 2014: Climate Change 2014: Synthesis Report. Contribution of Working Groups I, II and III to the Fifth Assessment Report of the Intergovernmental Panel on Climate Change .Geneva, Switzerland, 151 pp. (eds. Pachauri, R. K. \& Meyer, L.) Geneva, Switzerland, p. 138.

Kouwenberg, J. H. M. \& Lantoine, F. 2007: Effects of ultraviolet-B stressed diatom food on the reproductive output in Mediterranean Calanus helgolandicus (Crustacea; Copepoda). Journal of Experimental Marine Biology and Ecology, 341, 239-253.

This article is protected by copyright. All rights reserved. 
Lacuna, D. G. \& Uye, S. I. 2001: Influence of mid-ultraviolet (UVB) radiation on the physiology of the marine planktonic copepod Acartia omorii and the potential role of photoreactivation. Journal of Plankton Research, 23, 143-156(114).

Laspoumaderes, C., Souza, M. S., Modenutti, B. \& Balseiro, E. 2017: Glacier melting and response of Daphnia oxidative stress. Journal of Plankton Research, 39, 675686.

Leach, T. H., Williamson, C. E., Theodore, N., Fischer, J. M. et al. 2015: The role of ultraviolet radiation in the diel vertical migration of zooplankton: an experimental test of the transparency-regulator hypothesis. Journal of Plankton Research, 37, 886-896.

Lotocka, M. \& Styczynska-Jurewicz, E. 2001: Astaxanthin, canthaxanthin and astaxanthin esters in the copepod Acartia bifilosa (Copepoda, Calanoida) during ontogenetic development. Oceanologia, 43.

Lotocka, M., Styczyńska-Jurewicz, E. \& Blędzki, L. A. 2004: Changes in carotenoid composition in different developmental stages of copepods: Pseudocalanus acuspes Giesbrecht and Acartia spp. Journal of Plankton Research, 26, 159-166.

Lowry, O. H., Rosenbrough, N. J., Farr, A. L. \& Randall, R. J. 1951: Protein measurement with the Folin phenol reagent. Journal of Biological Chemistry, 193, 265-275.

Marinone, M. C., Menu Marque, S., Añón Suárez, D., Diéguez, M. D. C. et al. 2006: UV radiation as a potential driving force for zooplankton community structure in Patagonian lakes. Photochemistry and Photobiology, 82, 962-971.

Mladenov, N., Sommaruga, R., Morales-Baquero, R., Laurion, I. et al. 2011: Dust inputs and bacteria influence dissolved organic matter in clear alpine lakes. Nature Communications, 2, 405.

Modenutti, B. E. 1993: Summer population of Hexarthra bulgarica in a high altitude lake of South Andes. Hydrobiologia, 259, 33-37.

This article is protected by copyright. All rights reserved. 
Modenutti, B. E., Balseiro, E. G. \& Cervellini, P. M. 1993: Effect of selective feeding of Galaxias maculatus (Salmoniforme, Galaxiidae) on zooplankton of a South Andes lake. Aquatic Sciences, 55, 65-75.

Moeller, R. E., Gilroy, S., Williamson, C. E., Grad, G. et al. 2005: Dietary acquisition of photoprotective compounds (mycosporine-like amino acids, carotenoids) and acclimation to ultraviolet radiation in a freshwater copepod. Limnology and Oceanography, 50, 427-439.

Morris, D. P., Zagarese, H., Williamson, C. E., Balseiro, E. G. et al. 1995: The attenuation of solar UV radiation in lakes and the role of dissolved organic carbon. Limnology and Oceanography, 40, 1381-1391.

Pace, M. L. \& Cole, J. J. 2002: Synchronous variation of dissolved organic carbon and color in lakes. Limnology and Oceanography, 47, 333-342.

Perin, S. \& Lean, D. R. S. 2004: The effects of ultraviolet-B radiation on freshwater ecosystems of the Arctic: Influence from stratospheric ozone depletion and climate change. Environmental Reviews, 12, 1-70.

Persaud, A. D., Moeller, R. E., Williamson, C. E. \& Burns, C. W. 2007: Photoprotective compounds in weakly and strongly pigmented copepods and co-occurring cladocerans. Freshwater Biology, 52, 2121-2133.

Shurin, J. B., Winder, M., Adrian, R., Keller, W. et al. 2010: Environmental stability and lake zooplankton diversity - contrasting effects of chemical and thermal variability. Ecology Letters, 13, 453-463.

Sommaruga, R. 2010: Preferential accumulation of carotenoids rather than of mycosporine-like amino acids in copepods from high altitude Himalayan lakes. Hydrobiologia, 648, 143-156.

Souza, M. S., Balseiro, E. G., Laspoumaderes, C. \& Modenutti, B. E. 2010a: Effect of ultraviolet radiation on Acetylcholinesterase activity in freshwater copepods. Photochemistry and Photobiology, 86, 367-373.

This article is protected by copyright. All rights reserved. 
Souza, M. S., Hansson, L.-A., Hylander, S., Modenutti, B. E. et al. 2012: Rapid Enzymatic Response to Compensate UV Radiation in Copepods. PLoS One, 7, e32046.

Souza, M. S., Modenutti, B. E., Carrillo, P., Villar-Argaiz, M. et al. 2010b: Stoichiometric dietary constraints influence the response of copepods to ultraviolet radiation-induced oxidative stress. Limnology and Oceanography, 55, 1024-1032.

Sullivan, G. M. \& Feinn, R. 2012: Using effect size-or why the P value is not enough. Journal of graduate medical education, 4, 279-282.

Tartarotti, B., Baffico, G., Temporetti, P. \& Zagarese, H. E. 2004: Mycosporine-like amino acids in planktonic organisms living under different UV exposure conditions in Patagonian lakes. Journal of Plankton Research, 26, 753-762.

Tartarotti, B., Laurion, I. \& Sommaruga, R. 2001: Large variability in the concentration of mycosporine-like amino acids among zooplankton from lakes located across an altitude gradient. Limnology and Oceanography, 46, 1546-1552.

Tartarotti, B. \& Sommaruga, R. 2002: The effect of different methanol concentrations and temperatures on the extraction of mycosporine-like amino acids (MAAs) in algae and zooplankton. Archiv fur Hydrobiologie, 154, 691-703.

Tartarotti, B. \& Sommaruga, R. 2006: Seasonal and ontogenetic changes of mycosporinelike amino acids in planktonic organisms from an alpine lake. Limnology and Oceanography, 51, 1530-1541 Abstract.

Villafañe, V., Helbling, E. W. \& Zagarese, H. E. 2001: Solar ultraviolet radiation and its impact on aquatic systems of Patagonia, South America. Ambio, 30, 112-117.

Williamson, C. E. 1995: What role does UV-b radiation play in freshwater ecosystems? Limnology and Oceanography, 40, 386-392.

This article is protected by copyright. All rights reserved. 
Williamson, C. E. \& Rose, K. C. 2009: Ultraviolet Insights: Attempting to Resolve Enigmatic Patterns in Pelagic Freshwaters - The Historical Context and a View to the Future. International Review of Hydrobiology, 94, 129-142.

Williamson, C. E. \& Rose, K. C. 2010: When UV meets fresh water. Science, 329, 637639.

Williamson, C. E., Saros, J. E., Vincent, W. F. \& Smol, J. P. 2009: Lakes and reservoirs as sentinels, integrators, and regulators of climate change. Limnology and Oceanography, 54, 2273-2282.

Williamson, C. E., Stemberger, R. S., Morris, D. P., Frost, T. M. et al. 1996: Ultraviolet radiation in North American lakes: attenuation estimates from DOC measurements and implications for plankton communities. Limnology and Oceanography, 41, 1024-1034.

Zagarese, H., Diaz, M., Pedrozo, F. \& Ubeda, C. 2000: Mountain lakes in northwestern Patagonia. Internationale Vereinigung für theoretische und angewandte Limnologie: Verhandlungen, 27, 533-538.

Zagarese, H. E., Feldman, M. \& Williamson, C. E. 1997a: UV-B-induced damage and photoreactivation in three species of Boeckella (Copepoda, Calanoida). Journal of Plankton Research, 19, 357-367.

Zagarese, H. E., Williamson, C. E., Vail, T. L., Olsen, O. et al. 1997b: Long-term exposure of Boeckella gibbosa (Copepoda, Calanoida) to in situ levels of solar UVB radiation. Freshwater Biology, 37, 99-106.

Zellmer, I. d., Arts, M. t. \& Sustr, V. 2006: Food chain effects of sublethal ultraviolet radiation on subarctic Daphnia pulex a field and laboratory study. Archiv fur Hydrobiologie, 167, 515-531.

This article is protected by copyright. All rights reserved. 


\section{Tables}

Table 1. Features of Lakes Schmoll, Toncek, Escondido and Lake Verde.

\begin{tabular}{|c|c|c|c|c|}
\hline Lake & Schmoll & Toncek & Verde & Escondido \\
\hline Elevation (m.a.s.l.) & 1950 & 1750 & 1535 & 770 \\
\hline Maximum depth (m) & 5 & 12 & 5 & 8 \\
\hline $\mathrm{K}_{\mathrm{d} 305}\left(\mathrm{~m}^{-1}\right)^{*}$ & 0.17 & 0.72 & 2.50 & 8.88 \\
\hline $\mathrm{K}_{\mathrm{d} 320}\left(\mathrm{~m}^{-1}\right) *$ & 0.14 & 0.61 & 2.22 & 7.70 \\
\hline $\mathrm{K}_{\mathrm{dPAR}}\left(\mathrm{m}^{-1}\right)^{*}$ & 0.15 & 0.16 & 0.50 & 0.66 \\
\hline $\mathrm{Z}_{1 \% 320} * *(\mathrm{~m})$ & 33 & 7.5 & 2 & 0.6 \\
\hline Chlorophyll $a\left(\mu \mathrm{g} \mathrm{L}^{-1}\right)$ & $0.31 \pm 0.03$ & $0.61 \pm 0.13$ & $3.11 \pm 0.21$ & $1.83 \pm 0.18$ \\
\hline $\mathrm{DOC}\left(\mathrm{mg} \mathrm{L}^{-1}\right)$ & $0.33 \pm 0.02$ & $0.41 \pm 0.03$ & $2.34 \pm 0.53$ & $4.91 \pm 0.02$ \\
\hline Relative location to timberline & above & above & below & below \\
\hline $\mathrm{a}_{440}\left(\mathrm{~m}^{-1}\right)$ & 0.023 & 0.115 & 0.253 & 2.003 \\
\hline
\end{tabular}

This article is protected by copyright. All rights reserved. 
References: * Kd $=$ light attenuation coefficient $* * 1 \%$ attenuation depth for $320 \mathrm{~nm} . \mathrm{Kd}$ for Lake Verde, Toncek and Schmoll are from Morris et al. (1995).

Table 2. Light doses of field and laboratory experiments (4 h).

$$
\text { Field experiment Lab experiments }
$$

\begin{tabular}{lll}
\hline Wavelengths (nm) & Doses & Doses \\
\hline 305 & $442 \mathrm{~J} \mathrm{~m}^{-2} \mathrm{~nm}^{-1}$ & $576 \mathrm{~J} \mathrm{~m}^{-2} \mathrm{~nm}^{-1}$ \\
320 & $3961 \mathrm{~J} \mathrm{~m}^{-2} \mathrm{~nm}^{-1}$ & $3024 \mathrm{~J} \mathrm{~m}^{-2} \mathrm{~nm}^{-1}$ \\
340 & $6741 \mathrm{~J} \mathrm{~m}^{-2} \mathrm{~nm}^{-1}$ & $5040 \mathrm{~J} \mathrm{~m}^{-2} \mathrm{~nm}^{-1}$ \\
380 & $8928 \mathrm{~J} \mathrm{~m}^{-2} \mathrm{~nm}^{-1}$ & $8532 \mathrm{~J} \mathrm{~m}^{-2} \mathrm{~nm}^{-1}$ \\
$400-700$ & $22.75 \mathrm{~mol} \mathrm{photons} \mathrm{m}^{-2}$ & $1.4 \mathrm{~mol} \mathrm{photons} \mathrm{m}^{-2}$ \\
\hline
\end{tabular}

Table 3. Features of the two studied copepods B. gibbosa and B. gracilipes.
B. gibbosa
B. gracilipes

Lake Schmoll Toncek $\quad$ Verde $\quad$ Escondido

$\begin{array}{lllll}\text { Body length (mm) } & 0.887 \pm 0.013 & 0.918 \pm 0.013 & 0.996 \pm 0.033 & 0.920 \pm 0.074\end{array}$

This article is protected by copyright. All rights reserved. 


$\begin{array}{lcccc}\text { Total Carotenoids } & 1.70 \pm 0.08 & 1.97 \pm 0.07 & 1.81 \pm 0.07 & \text { Not detectable } \\ \mu \mathrm{g}(\mathrm{mg} \mathrm{DW})^{-1} & & & & \\ \text { MAAs } \mu \mathrm{g}(\mathrm{mg} \mathrm{DW})^{-1} & 6.49 \pm 0.70 & 4.98 \pm 0.30 & 2.67 \pm 0.89 & \text { Not detectable } \\ \text { GST Activity } & 2037 \pm 101 & 1378 \pm 257 & 1260 \pm 181 & 883 \pm 154 \\ & & & & \\ \begin{array}{l}\text { Copepod abundance } \\ \text { (ind.L } L^{-1} \text { ) }\end{array} & 2.3 & 20-30 & 36 & 1.5\end{array}$

Table 4. Composition and abundance (SE) of phytoplankton of Lake Verde in the feeding experiments. "Consumed" refers to phytoplankton that had lower abundance in the control than in the treatment and "not consumed" are the species that were is same abundance.

\begin{tabular}{lc} 
Consumed & Cells $\mathrm{mL}^{-1}$ \\
\hline Chrysocromulina parva & $5937 \pm 1364$ \\
Plagioselmis lacustris & $1593 \pm 182$ \\
Gymnodinium paradoxum & $20 \pm 4$ \\
Gonium sp. & $2543 \pm 277$ \\
& \\
Dyctiosphaerium sp. & $243 \pm 45$
\end{tabular}

Kirchneriella sp. $\quad 69 \pm 17$

This article is protected by copyright. All rights reserved. 
Cyclotella sp. $\quad 34 \pm 15$

Not consumed

Dinobryon divergens $\quad 432 \pm 44$

Dinobryon sertularia $\quad 390 \pm 45$

Aulacoseira granulata $\quad 69 \pm 34$

\section{Figures}

Figure 1. Light features in Lake Verde on the first day of the field experiment (a) UV and PAR surface irradiance around noon (b) Vertical light profile of Lake Verde as proportion of surface irradiance.
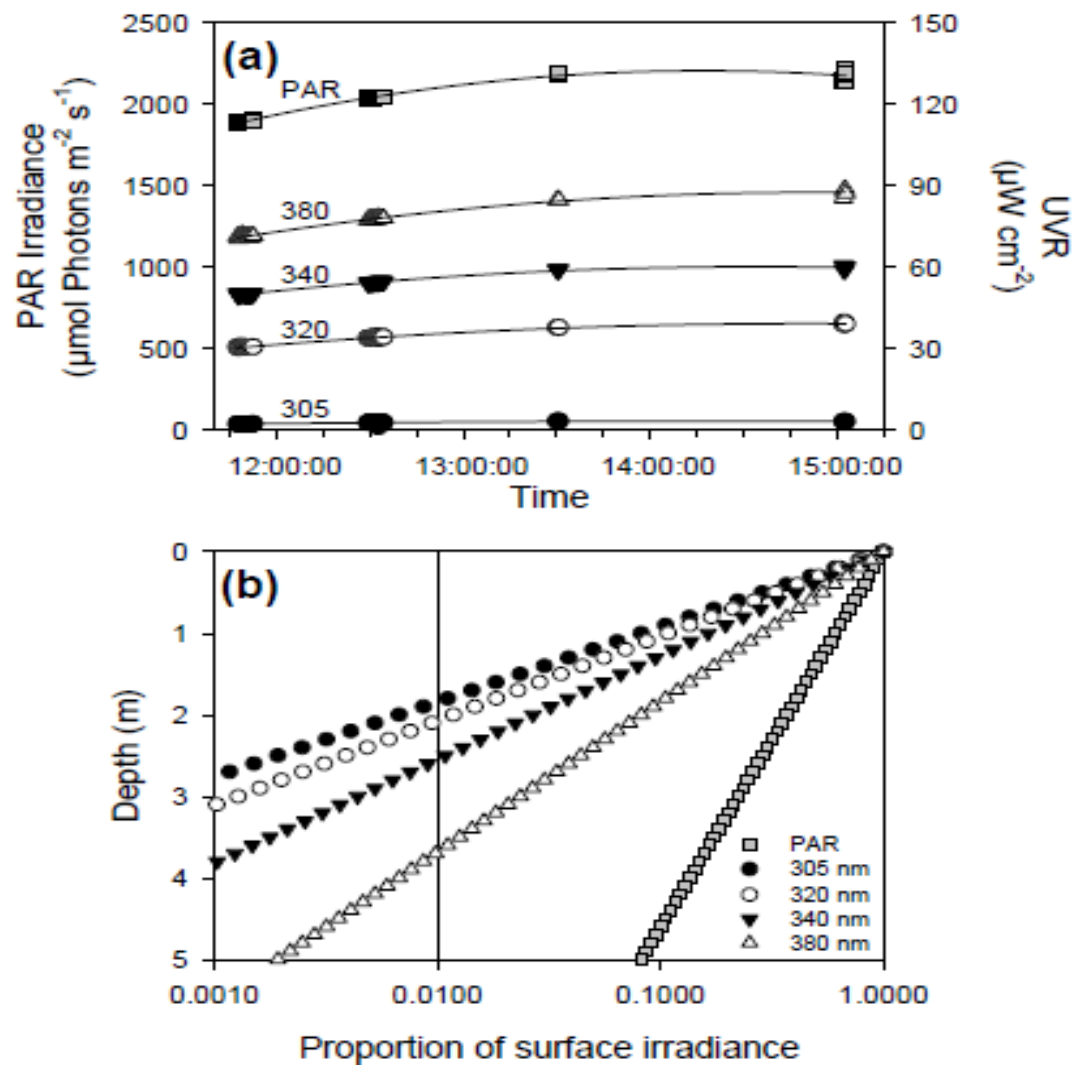

This article is protected by copyright. All rights reserved. 
Figure 2. Spectrophotometric absorbance spectra of the four studied lakes.

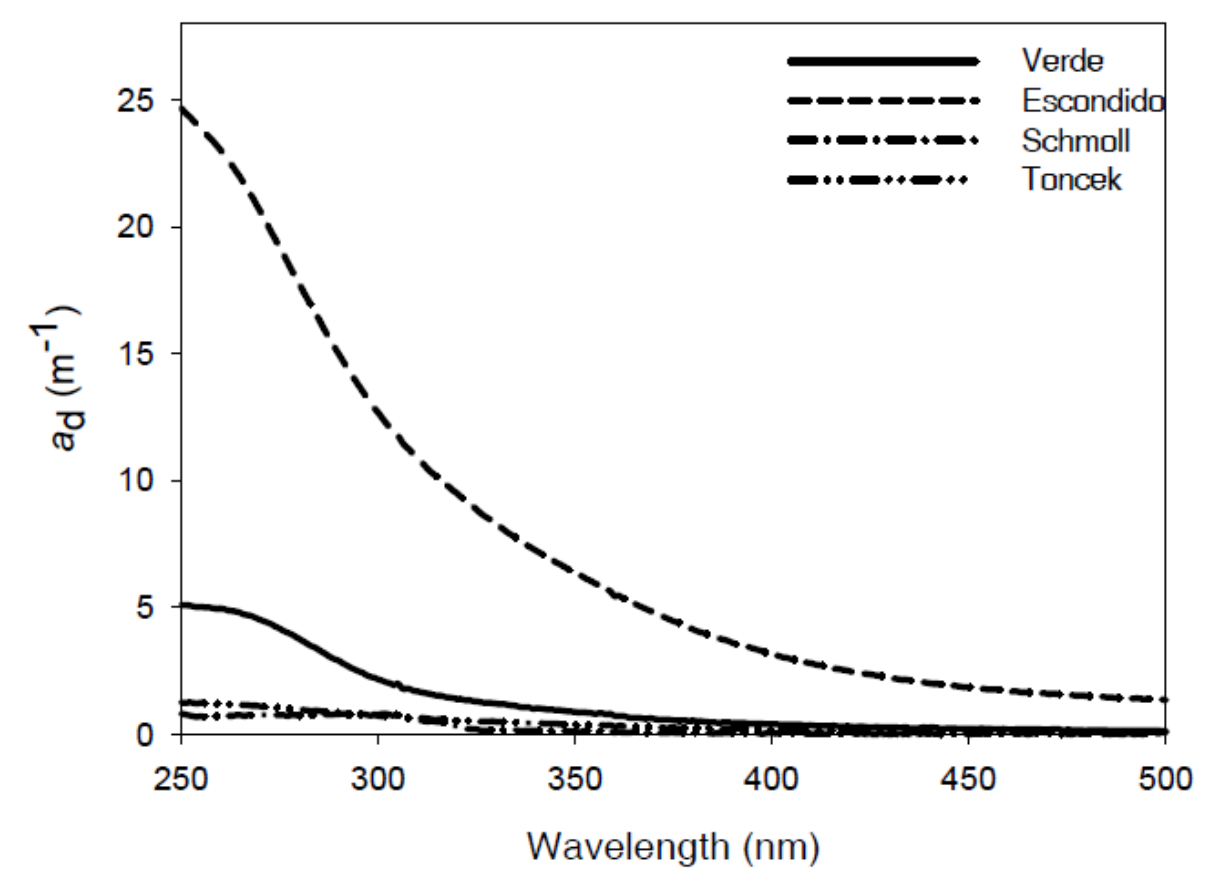

This article is protected by copyright. All rights reserved. 
Figure 3. Clearance rates in the laboratory experiments. (a) B. gracilipes from Lake Verde ( $p=0.008)$, (b) B. gracilipes from Lake Escondido ( $p<0.001)$ ), (c). B. gibbosa from Lake Schmoll ( $p=0.035)$, (d) B. gibbosa from Lake Toncek $(p<$ 0.001). (e) Field experiment: B. gracilipes in Lake Verde. Clearance rates are expressed in $\mathrm{mL}_{\mathrm{ind}}{ }^{-1} \mathrm{~h}^{-1}$. Error bars indicate 1 standard error. ES is the effect size as Cohen's $d$.
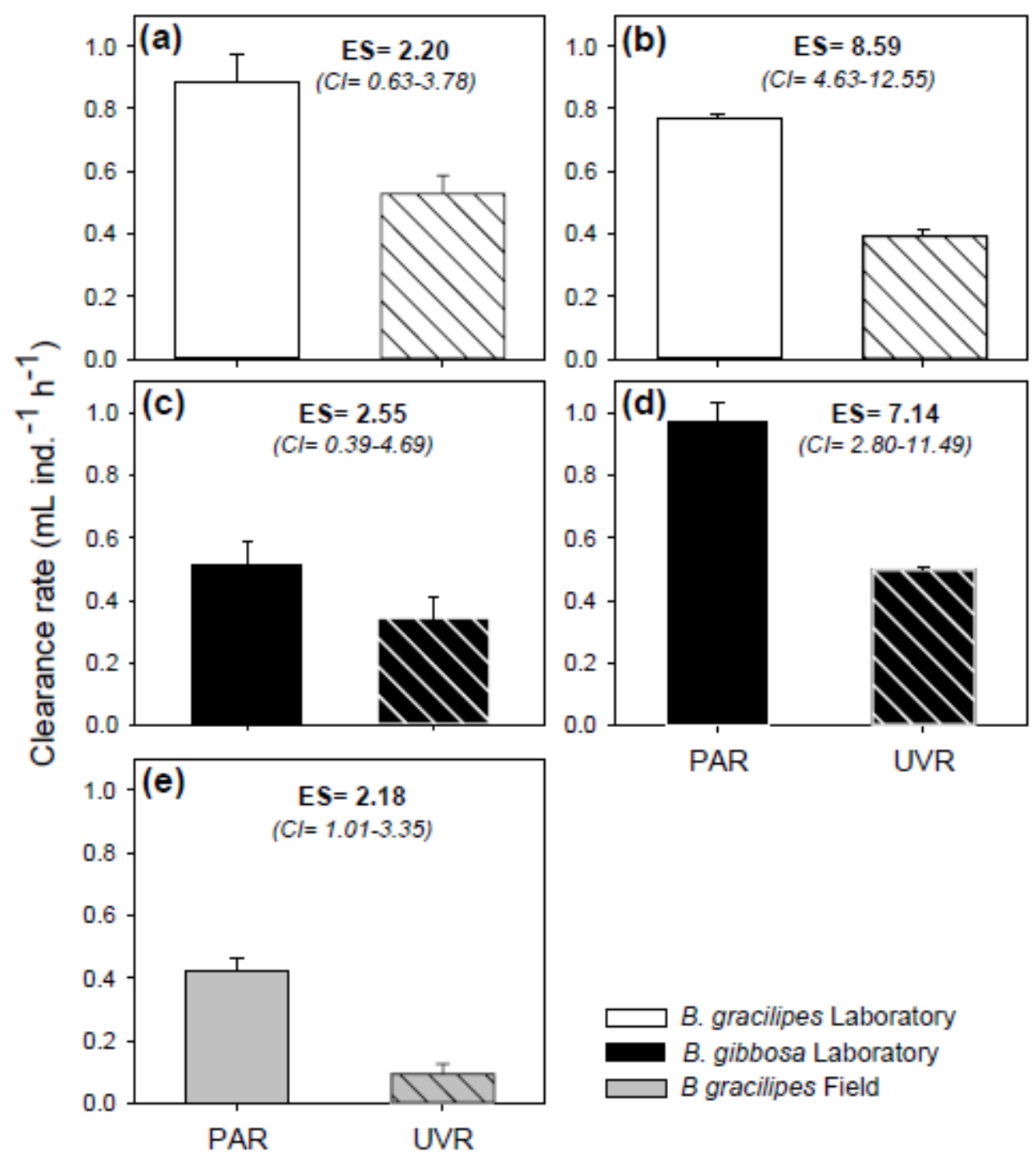

This article is protected by copyright. All rights reserved. 